DOI:10.17951/h.2020.54.4.55-68

\begin{tabular}{lcc}
\hline \multicolumn{4}{c}{ A N N A L E S } \\
UNIVERSITATIS MARIAE CURIE-SKŁODOWSKA \\
LUBLIN - POLONIA \\
SOL. LIV, 4 \\
\hline
\end{tabular}

\author{
ANDRZEJ KUCIŃSKI \\ akucinski@ajp.edu.pl \\ Akademia im. Jakuba z Paradyża w Gorzowie Wielkopolskim. Wydział Ekonomiczny \\ ul. Teatralna 25, 66-400 Gorzów Wielkopolski, Polska \\ ORCID ID: https://orcid.org/0000-0002-8988-8872
}

\title{
Programy automatycznej reinwestycji dywidendy jako instrument polityki wyplaty dywidendy w spółce akcyjnej
}

Dividend Reinvestment Programs as an Instrument of Dividend Payment Policy in a Joint Stock Company

Keywords: dividend; dividend policy; automatic dividend reinvestment programs

Slowa kluczowe: dywidenda; polityka dywidendy; plan automatycznej reinwestycji dywidendy

JEL: G30; G35

Propozycja cytowania: Kuciński, A. (2020). Programy automatycznej reinwestycji dywidendy jako instrument polityki wypłaty dywidendy w spółce akcyjnej. Annales Universitatis Mariae Curie-Skłodowska, sectio H-Oeconomia, Vol. 54, No. 4.

\footnotetext{
Abstract

Theoretical background: The issue of automatic dividend reinvestment programs is rarely discussed in Polish literature, there are no comprehensive studies on automatic dividend reinvestment programs. This issue most often appears when discussing the tools of dividend policy.

Purpose of the article: Presentation of the assumptions of automatic dividend reinvestment programs (plans), which can be an instrument of the dividend payment policy in a joint stock company, as well as analysis of the automatic dividend reinvestment programs offered by 30 American companies representing Dow Jones Industrial Average Index.
}

Research methods: The study is based on a literature review and a documents (brochures) analysis describing dividend reinvestment programs.

Main findings: Dividend reinvestment programs have been implemented by all companies included in the Dow Jones Industrial Average Index. A significant part of the analyzed programs belongs to the group of 
the so-called No-Fee Dividend Reinvestment Programs. The observations made show that often dividend reinvestment programs are supplemented by additional share purchase programs called Optional Cash Purchase Plans (OCPs) or Stock Purchase Plans (SPPs).

\begin{abstract}
Abstrakt
Uzasadnienie teoretyczne: Zagadnienie programów automatycznej reinwestycji dywidendy jest rzadko poruszane w polskiej literaturze, brak jest całościowych opracowań dotyczących programów automatycznej reinwestycji dywidendy. Zagadnienie to najczęściej pojawia się przy omawianiu narzędzi polityki dywidendy. Cel artykułu: Przedstawienie założeń programów (planów) automatycznej reinwestycji dywidendy, które mogą stanowić narzędzie polityki wypłaty dywidendy w spółce akcyjnej, a także dokonanie analizy programów automatycznej reinwestycji dywidendy oferowanych przez 30 amerykańskich spółek reprezentujących Dow Jones Industrial Average Index.

Metody badawcze: W opracowaniu wykorzystano jako metody badawcze analizę literatury oraz analizę dokumentów (broszur) opisujących programy automatycznej reinwestycji dywidendy.

Główne wnioski: Programy automatycznej reinwestycji dywidendy zostały wdrożone przez wszystkie spółki wchodzące w skład Dow Jones Industrial Average Index. Znaczna część analizowanych programów zalicza się do grupy tzw. bezpłatnych programów reinwestycji dywidendy (No-Fee Dividend Reinvestment Programs). $\mathrm{Z}$ dokonanych obserwacji wynika, że często programy automatycznej reinwestycji dywidendy uzupełniane są o dodatkowe programy zakupu akcji, określane jako Optional Cash Purchase Plans (OCPs) lub Stock Purchase Plans (SPPs).
\end{abstract}

\title{
Wprowadzenie
}

Współczesne rynki finansowe cechuje złożona infrastruktura oraz szeroki zakres stosowanych instrumentów finansowych. Nieodzownym ich elementem są różnego rodzaju rozliczenia finansowe, którym towarzyszą przepływy pieniężne. I tak emitenci (przedsiębiorstwa), sprzedając papiery wartościowe, pozyskują kapitał w formie gotówki, z kolei inwestorzy (właściciele), nabywając papiery wartościowe, udostępniają swoje wolne zasoby pieniężne spółkom. Tym samym osoby dysponujące papierami wartościowymi mogą osiągnąć korzyści finansowe w postaci zysku kapitałowego, czyli wzrostu wartości rynkowej papieru wartościowego ponad jego cenę nabycia, czy też dywidendy.

Decyzje związane z podziałem zysku netto w przedsiębiorstwie, ale także rozstrzygnięcia dotyczące wysokości dywidendy oraz wyboru jej formy wypłaty należą do ważniejszych obszarów zarządzania finansowego przedsiębiorstwa. Założenia polityki wypłaty dywidendy coraz częściej wykraczają poza zakres klasycznej dywidendy pieniężnej. Elementem nowoczesnej polityki wypłat na rzecz akcjonariuszy mogą być programy (plany) reinwestycji dywidendy (dividend reinvestment programs/ plans, DRIPs), gdzie środki uzyskane z wypłacanych dywidend przeznaczane są na zakup papierów wartościowych. Programy są popularne i często stosowane w krajach wysoko rozwiniętych, w tym m.in. w takich państwach, jak Stany Zjednoczone Ameryki, Kanada, Australia czy Nowa Zelandia. Biorąc pod uwagę to, że tego rodzaju instrumenty nie są dostępne na rynku kapitałowym w Polsce oraz zauważalny jest 
brak tego typu badań na gruncie polskim, zdecydowano się na przybliżenie założeń i celu realizowanych programów automatycznej reinwestycji dywidendy.

Celem artykułu jest przedstawienie założeń programów (planów) automatycznej reinwestycji dywidendy, które mogą stanowić podstawę budowy nowoczesnej polityki wypłaty dywidendy w spółce akcyjnej, a także analiza funkcjonujących programów reinwestycji dywidendy oferowanych przez 30 amerykańskich spółek reprezentujących Dow Jones Industrial Average Index. Do osiągnięcia założonego celu wykorzystano analizę literatury oraz analizę dokumentów (broszur) opisujących programy automatycznej reinwestycji dywidendy spółek tworzących Dow Jones Industrial Average Index.

\section{Istota i znaczenie programów automatycznej reinwestycji dywidendy}

Dywidenda wiąże się z jednym z podstawowych praw majątkowych akcjonariuszy - prawem do udziału w zysku netto spółki. Przez dywidendę należy rozumieć część zysku spółki, która przysługuje jej akcjonariuszom (udziałowcom, właścicielom) (Kaźmierska-Jóźwiak, 2019, s. 21). W praktyce rynków kapitałowych dywidendy mogą być wypłacane w trzech głównych jej formach: dywidendy pieniężnej, dywidendy niepieniężnej lub w innej formie (Sierpińska, 1999, s. 61).

Zestaw instrumentów pozwalających na redystrybucję zysków wypracowanych przez przedsiębiorstwo do akcjonariuszy jest szeroki. Obok dywidendy pieniężnej (cash dividend), która wciąż cieszy się niesłabnącą popularnością, można wyróżnić dywidendę bezgotówkową (non-cash divdidend) (Pieloch, 2013, s. 436), nabycie akcji własnych (buy back; inaczej „odkup”, ,zakup zwrotny”- zob. Kuciński \& Byczkowska, 2017, s. 132) lub programy (plany) automatycznej reinwestycji dywidendy (dividend reinvestment programs/plans, DRIPs) (Zarębski, 2013, s. 609).

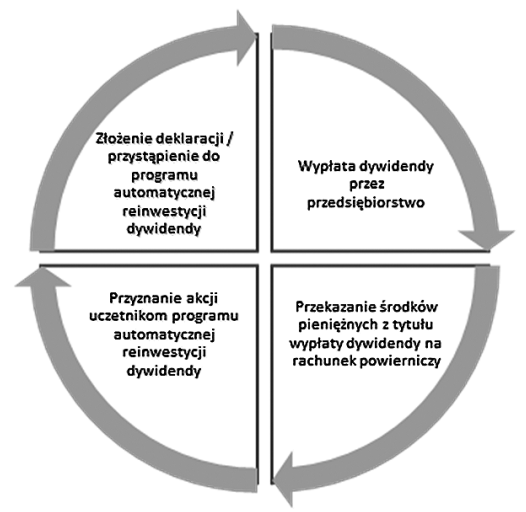

Rysunek 1. Ogólny schemat funkcjonowania planu (programu) automatycznej reinwestycji dywidendy 
Programy (plany) automatycznej reinwestycji dywidendy, ogłaszane przez spółki, zapewniają swoim akcjonariuszom reinwestowanie całości lub części dywidendy w dodatkowe akcje przedsiębiorstwa z pominięciem maklera oraz towarzyszących opłat transakcyjnych, a także zwykle po cenie niższej od ceny rynkowej (Chan, McColough, \& Skully, 1995, s. 79; Chiang, Frankfurter, \& Kosedag 2005, s. 571).

Plany automatycznej reinwestycji dywidendy tworzą przedsiębiorstwa, a ich uczestnicy zyskują możliwość reinwestowania dywidend gotówkowych w dodatkowe akcje. Zgodnie z rysunkiem 1 uczestnictwo w programie nie jest automatyczne $\mathrm{z}$ racji posiadania udziałów w przedsiębiorstwie, lecz odbywa się poprzez złożenie deklaracji o przystąpieniu do programu. Jeżeli przyłączenie do programu nastąpiło przed dniem rejestracji akcji uprawniających do otrzymania dywidendy, to formalnie od tego momentu wypłacane dywidendy gotówkowe kierowane są na rachunek powierniczy, z którego nabywane są akcje spółek biorących udział w programie. Środki pieniężne zagregowane od wszystkich uczestników planu wykorzystywane są do zakupu akcji, a następnie proporcjonalnie do wpływów $\mathrm{z}$ dywidendy pieniężnej są rozliczane i rozdzielane na indywidualne konta inwestorów.

W praktyce wyróżnia się dwa podstawowe rodzaje planów, które różnią się sposobem nabywania akcji w celu ich dalszej dystrybucji do uczestników programu (Larkin, Lee, \& Wane, 2005, s. 55). Są to:

1) plan reinwestycji dywidendy z tytułu odkupu (repurchase dividend reinvestment plan - repurchase DRIP),

2) plan reinwestycji dywidendy nowo emitowanych akcji (new issue dividend reinvestment plan - new issue DRIP).

$\mathrm{W}$ przypadku pierwszego rozwiązania plany reinwestycji dywidendy z tytułu odkupu zakładają nabycie akcji na otwartym rynku (open market dividend reinvestment plan). W ramach tego rodzaju programów nie są emitowane nowe akcje, lecz wykorzystywane są dotychczasowe akcje (tzw. stare akcje, będące już w obrocie). Przedsiębiorstwo lub jego agent transferowy kupuje akcje na rynku, by następnie we właściwej proporcji przydzielić je poszczególnym uczestnikom programu reinwestycji dywidendy. W zasadzie tego rodzaju programy (plany) automatycznej reinwestycji dywidendy bazują na programie skupu akcji własnych. Nabywane w ramach programów automatycznej reinwestycji dywidendy papiery wartościowe obejmowane są z reguły po cenie rynkowej, choć w przypadku niektórych programów dla ich uczestników może być zastosowane dyskonto pozwalające zakupić akcje po niższej cenie niż rynkowa. Koszty związane z uczestnictwem w programie najczęściej ponosi jego uczestnik, choć występują też programy, gdzie koszty związane z uczestnictwem w programie subsydiuje przedsiębiorstwo (Baker \& Powell, 2005, s. 438).

Plany reinwestycji dywidendy nowo emitowanych akcji to rodzaj planów, które umożliwiają akcjonariuszom zakup nowych akcji bezpośrednio od spółki. W ramach tych programów uczestnicy za środki zgromadzone z otrzymanych dywidend pieniężnych obejmują akcje nowej emisji. Tego rodzaju plany tworzą alternatywną formę dla tradycyjnego pozyskania kapitału własnego w drodze sprzedaży akcji na 
rynku pierwotnym. Uczestnicy programów mają możliwość nabycia akcji nowej emisji z dyskontem, a przedsiębiorstwa ogłaszające plany reinwestycji dywidendy mają możliwość m.in. podniesienia kapitałów własnych, zmniejszenia poziomu zadłużenia czy zatrzymania strumienia gotówki w związku z wypłatą dywidendy pieniężnej (Baker \& Powell, 2005, s. 438).

W literaturze można odnaleźć również inne kryteria podziału programów automatycznej reinwestycji dywidendy. Ze względu na rodzaj podmiotu obsługującego programy automatycznej reinwestycji dywidendy (Baker, 2009, s. 344) wyróżnia się :

- plany automatycznej reinwestycji dywidendy obsługiwane samodzielnie przez przedsiębiorstwo (company operated dividend reinvestment plans),

- plany automatycznej reinwestycji dywidendy obsługiwane przez agenta transferowego (agent operated dividend reinvestment plans),

- plany automatycznej reinwestycji dywidendy obsługiwane przez brokera (brokerage operated dividend reinvestment plans).

W przypadku planów reinwestycji dywidendy obsługiwanych przez samo przedsiębiorstwo powoływany jest specjalny dział, do którego zadań należy nie tylko promowanie programu, lecz także organizowanie i koordynowanie wszelkich czynności związanych z reinwestowaniem dywidendy. Deklaracje związane z przystąpieniem do programu kierowane są bezpośrednio do przedsiębiorstwa organizującego plany automatycznej reinwestycji dywidendy. Uczestnikom planów reinwestycji dywidendy w dniu rozliczenia rozdzielane są akcje pochodzące $\mathrm{z}$ własnych rezerw lub konta akcji własnych przedsiębiorstwa, które później nie są przedmiotem obrotu na giełdzie. Dzięki temu udziały nabyte przez inwestorów mogą być sprzedane wyłącznie bezpośrednio spółce (Baker, 2009, s. 344).

Zarządzanie planami automatycznej reinwestycji dywidendy samodzielnie przez przedsiębiorstwo może być kłopotliwe i czasochłonne. W takiej sytuacji spółka może zlecić obsługę programów automatycznej reinwestycji dywidendy agentowi transferowemu, którym może być bank lub inna instytucja finansowa. Tym samym agenci transferowi zapewniają akcjonariuszom dostęp do informacji o planie reinwestycji dywidendy oraz obsługę obejmującą rejestrację w programie i reinwestycję środków pochodzących z dywidend (Baker, 2009, s. 344).

Na rynku mogą też występować plany reinwestycji dywidendy obsługiwane przez brokerów. Mogą one dotyczyć przedsiębiorstw, które formalnie takiego programu nie ogłosiły. Domy maklerskie - wychodząc naprzeciw oczekiwaniom inwestorów - tworzą plany, które pozwalają reinwestować otrzymane dywidendy pieniężne. Formalnie oznacza to zakup akcji na otwartym rynku, a następnie ich dodanie do rachunku maklerskiego inwestorów. Akcje otrzymane w ramach planów reinwestycji dywidend mogą być potem sprzedawane na wtórnym rynku giełdowym (Baker, 2009, s. 344-345).

Z funkcjonowaniem programów automatycznej reinwestycji dywidendy wiąże się wiele korzyści, jednakże oprócz pozytywnych aspektów można wyróżnić także pewne ich wady, które zestawiono i zaprezentowano w tabeli 1. 
Pobrane z czasopisma Annales H - Oeconomia http://oeconomia.annales.umcs.pl

Data: 26/04/2023 11:10:38

Tabela 1. Zalety i wady programów automatycznej reinwestycji dywidendy

\begin{tabular}{|c|c|}
\hline \multicolumn{2}{|c|}{ Programy automatycznej reinwestycji dywidendy } \\
\hline zalety & wady \\
\hline $\begin{array}{l}\text { Elastyczność programu - przejawia się w tym, że } \\
\text { uczestnik programu w każdej chwili może zarówno } \\
\text { przystąpić do programu, jak i z niego zrezygnować. } \\
\text { Srodki na zakup akcji mogą pochodzić nie tylko z wy- } \\
\text { płacanych dywidend, lecz także mogą być uzupełniane } \\
\text { o dodatkowe środki pochodzące z samodzielnych wpłat } \\
\text { uczestników. Przedsiębiorstwa - w zależności od swoich } \\
\text { potrzeb kapitałowych - mogą zdecydować o rodzaju } \\
\text { uruchamianego planu (nabywanie w ramach programu } \\
\text { nowych akcji istniejących) }\end{array}$ & $\begin{array}{l}\text { Konieczność uiszczenia podatków od reinwestowanych } \\
\text { dywidend - niezależnie od tego, czy dywidendy są wy- } \\
\text { płacane w formie pieniężnej czy też jej środki kierowane } \\
\text { są na zakup dodatkowych akcji w ramach reinwestycji dy- } \\
\text { widendy, powstaje obowiązek podatkowy, z którym wiąże } \\
\text { się konieczność zapłaty podatku od zysków kapitałowych }\end{array}$ \\
\hline $\begin{array}{l}\text { Niskie opłaty lub brak opłat - transakcjom zakupu akcji } \\
\text { towarzyszą z reguły niskie opłaty lub w ogóle nie wystę- } \\
\text { pują, jeśli przedsiębiorstwo zdecyduje o subsydiowaniu } \\
\text { kosztów związanych z uczestnictwem w programie }\end{array}$ & $\begin{array}{l}\text { Nakłady organizacyjne - wprowadzenie i realizacja pro- } \\
\text { gramu reinwestycji dywidend wymagają utrzymania działu } \\
\text { odpowiedzialnego za prowadzenie programu reinwestycji } \\
\text { dywidendy, a także przygotowania dokumentów infor- } \\
\text { macyjnych na temat warunków i zasad funkcjonowania } \\
\text { programu czy też zawarcia umowy z agentem transfero- } \\
\text { wym bądź brokerem, którego głównym zadaniem będzie } \\
\text { zarządzanie programem }\end{array}$ \\
\hline $\begin{array}{l}\text { Wzmocnienia i poprawa struktury kapitałowej w przed- } \\
\text { siębiorstwie - dywidendy pieniężne reinwestowane } \\
\text { w nowo emitowane akcje prowadzą do podwyższenia } \\
\text { kapitału własnego w przedsiębiorstwie oraz do zmniej- } \\
\text { szenia poziomu jego zadłużenia, jednocześnie poprawia } \\
\text { się relacja między kapitałem własnym a obcym } \\
\end{array}$ & $\begin{array}{l}\text { Ukryte koszty związane z uczestnictwem w programie } \\
\text { reinwestycji dywidendy - o ile transakcjom zakupu akcji } \\
\text { w ramach programu reinwestycji dywidendy towarzyszą } \\
\text { z reguły niskie koszty lub brak opłat, o tyle przy sprzedaży } \\
\text { udziałów mogą wystąpić znaczne koszty wpływające na } \\
\text { efektywność całej inwestycji }\end{array}$ \\
\hline $\begin{array}{l}\text { Poszerzenie i wzmocnienie określonych grup akcjona- } \\
\text { riuszy - programy kierowane są głównie do drobnych } \\
\text { akcjonariuszy, dzięki czemu zwiększa się udział inwesto- } \\
\text { rów indywidualnych w strukturze właścicielskiej, dopro- } \\
\text { wadzając do rozproszenia i zróżnicowania akcjonariatu }\end{array}$ & $\begin{array}{l}\text { Rozwodnienie kapitału - programy reinwestycji dywiden- } \\
\text { dy oparte na nowej emisji akcji prowadzą do rozwodnienia } \\
\text { akcjonariatu oraz do zmniejszenia zysku na jedną akcję }\end{array}$ \\
\hline $\begin{array}{l}\text { Wzrost wartości przedsiębiorstwa / wsparcie cen rynko- } \\
\text { wych - nabywanie akcji w ramach programu prowadzi } \\
\text { do zwiększonej presji zakupowej, która przekłada się } \\
\text { na wzrost cen akcji i wyceny rynkowej spółki; zakupy } \\
\text { w ramach programu mogą działać stabilizująco na cenę } \\
\text { rynkową akcji }\end{array}$ & $\begin{array}{l}\text { Brak wpływu na moment zakupu akcji - uczestnicy pro- } \\
\text { gramu reinwestycji dywidendy nie mają wpływu na mo- } \\
\text { ment zakupu reinwestowanych dywidend, które nabywane } \\
\text { są zgodnie z harmonogramem, regulaminem zakupu akcji }\end{array}$ \\
\hline $\begin{array}{l}\text { Uśrednienie kosztów zakupu (dollar-cost averaging) } \\
\text { - nabywanie akcji w ramach programu ma charakter } \\
\text { periodyczny, długoterminowy, co pozwala uśrednić } \\
\text { cenę nabycia akcji oraz zmniejszyć wpływ zmienności } \\
\text { w portfelu inwestycyjnym }\end{array}$ & $\begin{array}{l}\text { Długoterminowy charakter inwestycji - programy au- } \\
\text { tomatycznej reinwestycji dywidendy są nieodpowiednie } \\
\text { dla inwestorów krótkoterminowych, uzyskanie wymier- } \\
\text { nych korzyści finansowych wymaga bowiem założenia } \\
\text { długoterminowego horyzontu inwestycyjnego }\end{array}$ \\
\hline \begin{tabular}{|l|} 
Udzielone dyskonto od ceny zakupu akcji - niekiedy \\
programy reinwestycji zakupu przewidują udzielenie \\
dyskonta, co pozwala nabyć akcje po cenie niższej niż \\
ich aktualna cena rynkowa \\
\end{tabular} & \\
\hline $\begin{array}{l}\text { Niższe koszty finansowania - pozyskanie kapitału } \\
\text { w ramach programu reinwestycji dywidendy może } \\
\text { okazać się niższe niż w przypadku innych źródeł } \\
\text { finansowania }\end{array}$ & \\
\hline
\end{tabular}

Źródło: opracowanie własne na podstawie (Baker, 2009, s. 348, 352-354; Baker, Khan, \& Mukherjee, 2002, s. 51-61; Bierman, 1997, s. 268; Cherin \& Hanson, 1995, s. 61; Petway \& Malone, 1973, s. 11-18). 


\section{Przegląd literatury - główne nurty badawcze}

Programy automatycznej reinwestycji dywidendy pozwalają ich uczestnikom wykorzystać otrzymane dywidendy pieniężne na zakupy dodatkowych udziałów. Stany Zjednoczone Ameryki stanowią przykład kraju, w którym plany reinwestycji dywidend są szczególnie popularne. Pierwsze plany reinwestycji dywidendy w USA pojawiły się pod koniec lat 60 . XX wieku, kiedy spółka AT\&T zaoferowała swoim akcjonariuszom możliwość zakupu akcji za środki pochodzące z wypłaconych dywidend pieniężnych. Początkowo programy pozwalały jedynie na reinwestycję części lub całości dywidendy pieniężnej. Z czasem uczestnicy programów zyskali możliwość nie tylko reinwestowania dywidend, lecz także zakupu nowych akcji z własnych wpłat. Liczba spółek oferujących możliwość reinwestowania dywidend w USA nieustannie rośnie. Obecnie dostępnych jest ponad 1200 programów automatycznej reinwestycji dywidendy w $\mathrm{USA}^{1}$.

Zagadnienie reinwestycji dywidendy w literaturze naukowej jest rzadko poruszane, choć programy pozwalające nabyć akcje z wypłacanych dywidend pieniężnych funkcjonują od wielu lat. Problematyka badawcza dotycząca programów reinwestycji dywidendy poruszana w literaturze naukowej obejmuje trzy zasadnicze obszary:

1) analizę wpływu efektu daty wypłaty dywidendy na stopę zwrotu spółek oferujących programy reinwestycji dywidendy,

2) ocenę programów automatycznej reinwestycji dywidendy jako metody pozyskiwania nowego kapitału,

3) analizę czynników determinujących decyzje o oferowaniu programów reinwestycji dywidendy (Chiang i in., 2005, s. 574-576).

Pierwszy z wyodrębnionych obszarów badań podejmowanych w literaturze naukowej koncentruje swoją uwagę na kwestii wpływu programów automatycznej reinwestycji dywidendy na osiągane stopy zwrotu przez uczestników programów. Badania na temat zachowania cen akcji wokół daty wypłaty dywidendy jako jeden z pierwszych badaczy analizował Ogden. Na podstawie przeprowadzonych badań wykazał, że stopy zwrotu w okresach płatności dywidend są wyższe dla spółek realizujących programy automatycznej reinwestycji dywidendy (Ogden, 1994, s. 345). Z kolei Berkman i Koch uzyskali dowody na to, że w dniu wypłaty dywidendy, zgodnie z hipotezą presji cenowej, ma miejsce znaczący wzrost ceny akcji, który pozwala uzyskać dodatnią ponadprzeciętną stopę zwrotu na skutek tymczasowego zwiększenia zapotrzebowania na akcje nabywane w ramach programu reinwestycji dywidendy (Berkman \& Koch, 2017, s. 1793-1794). W tym miejscu należy zaznaczyć, że istnieją również badania, które podważają ustalenia o możliwości uzyskania anormalnych stóp zwrotu w okresach wypłaty dywidendy i jej reinwestycji.

Liczba ta obejmuje programy oferowane przez spółki zarówno amerykańskie, jak i zagraniczne, notowane na giełdach w USA (www.dripinvestor.com/index.asp). 
Zgodnie z przyjętą taksonomią problemy badawcze poruszane w ramach drugiego obszaru odnoszą się do tego, czy programy automatycznej reinwestycji stanowią efektywną metodę pozyskania finansowania. Na uwagę zasługują badania Scholesa i Wolfsona, którzy analizowali dyskonto udzielane przy nabywaniu akcji w ramach programów reinwestycji dywidendy. Według nich programy automatycznej reinwestycji dywidendy z dyskontem pozwalają uniknąć opłat z tytułu gwarantowania emisji oraz innych kosztów ponoszonych przy pozyskaniu nowego kapitału. Jednocześnie zauważają, że firmy rezygnują z udzielanych zniżek przy nabywaniu akcji w ramach programów reinwestycji dywidendy po uzyskaniu docelowego poziomu kapitału (Scholes \& Wolfson, 1989, s. 26-27). Z kolei Finnerty w swoich badaniach dowodzi, że pozyskanie kapitału w ramach planu reinwestycji dywidendy nowo emitowanych akcji zapewnia przedsiębiorstwu tańsze źródło kapitału własnego niż w przypadku bezpośredniej sprzedaży akcji (Finnerty, 1989, s. 127). Z rezultatów innych badań wynika, że przedsiębiorstwa inicjują programy automatycznej reinwestycji dywidendy nowej emisji akcji wtedy, gdy mają zwiększone potrzeby kapitałowe, a następnie ich zaprzestają, gdy zmniejsza się zapotrzebowanie na finansowanie zewnętrzne (Mukherjee, Baker, \& Hingorani, 2002, s. 294). Plany nowej emisji wdrażane są z reguły przez przedsiębiorstwa znajdujące się $\mathrm{w}$ fazie szybkiego rozwoju, które potrzebują finansowania zewnętrznego, gdyż ich kapitał wewnętrzny jest niewystarczający do sfinansowania tego wzrostu (Mukherjee, He, \& Baker, 2012, s. 122-123).

Trzeci aspekt badań poruszanych w literaturze dotyczy zagadnień związanych z ustaleniem czynników determinujących decyzje o oferowaniu programów automatycznej reinwestycji dywidendy. Pionierskie badania przeprowadzili Boehm i DeGennaro, którzy za cel przyjęli określenie profilu przedsiębiorstwa wdrażającego programy automatycznej reinwestycji dywidendy oraz określenie zmiennych wpływających na decyzje o utrzymaniu programu reinwestycji dywidendy w spółce. Autorzy na podstawie modelu logitowego - próby obejmującej 1704 oberwacje, w skład której weszły 852 przedsiębiorstwa oferujące programy automatycznej reinwestycji dywidendy oraz 852 przedsiębiorstwa, które takich programów nie posiadały - wykazali, że stopa dywidendy, zdolność do wypłaty dywidendy oraz zwiększenie kontroli menedżerskiej mają największy wpływ na prawdopodobieństwo posiadania przez przedsiębiorstwo programu automatycznej reinwestycji dywidendy (Boehm \& DeGennaro, 2007, s. 2-17). Z kolei Larkin, Lee i Wane (2005, s. 58-60) wyodrębnili determinanty z perspektywy menedżerów, wskazując między innymi, że wielkość przedsiębiorstwa, pakiet akcji menedżerskich oraz wolne przepływy pieniężne to czynniki wyjaśniające decyzję o korzystaniu przez przedsiębiorstwo z programu automatycznej reinwestycji dywidendy.

$\mathrm{Na}$ gruncie polskiej literatury istnieją nieliczne prace poświęcone programom automatycznej reinwestycji dywidendy. Problem w literaturze przez polskich badaczy jest najczęściej sygnalizowany przy omawianiu zagadnienia polityki dywidendy. $\mathrm{Na}$ tym tle na uwagę zasługuje praca Zarębskiego, który analizował możliwość zastosowania programów automatycznej reinwestycji dywidendy w małych i średnich 
przedsiębiorstwach. Autor przedstawił podstawowe zalety i wady wprowadzenia programów automatycznej reinwestycji dywidendy w mniejszych spółkach (Zarębski, 2011, s. 183-187).

\section{Analiza planów (programów) automatycznej reinwestycji dywidendy na przykładzie spółek wchodzących w skład Dow Jones Industrial Average Index}

Programy automatycznej reinwestycji dywidendy pozwalają reinwestować dywidendę gotówkową w akcje spółek, które te dywidendy wypłacają. Biorąc pod uwagę poziom rozwoju poszczególnych rynków finansowych oraz ich znaczenie w ujęciu globalnym, zdecydowano się na analizę programów automatycznej reinwestycji dywidendy oferowanych w USA, a dokładniej na zbadanie programów oferowanych przez przedsiębiorstwa wchodzące w skład Dow Jones Industrial Average Index. Próbę badawczą stanowiło 30 największych amerykańskich spółek (tzw. blue chips) notowanych na New York Stock Exchange i NASDAQ o ugruntowanej pozycji rynkowej i dobrej sytuacji finansowej. Przedsiębiorstwa zaliczane do blue chips cechują się dużą kapitalizacją i płynnością oraz systematycznie wypłacają dywidendy.

Funkcjonujące programy automatycznej reinwestycji dywidendy w USA najczęściej administrowane i prowadzone są samodzielnie przez przedsiębiorstwa oferujące programy bądź też zarządzane są przez agentów transferowych, którzy zajmują się obsługą programów prowadzonych w imieniu spółki. Do największych agentów transferowych w USA należą m.in.: American Stock Transfer \& Trust Company, obsługujący około 25\% wszystkich spółek publicznych w Ameryce Północnej; Computershare Limited - globalny agent działający w kilku krajach na pięciu kontynentach; Wells Fargo Shareowner Services. American Stock Transfer, Computershare oraz Wells Fargo obsługują ponad 65\% korporacji i 75\% udziałowców w amerykańskich spółkach publicznych.

Programy automatycznej reinwestycji dywidendy w Stanach Zjednoczonych oferuje wiele przedsiębiorstw. Tworzą one długoterminową strategię inwestycyjną z wykorzystaniem rynku kapitałowego, pozwalającą na akumulowanie w portfelu udziałów spółek wypłacających regularne dywidendy. Taką regularność można zaobserwować w grupie przede wszystkim dużych przedsiębiorstw, które często - zgodnie z przyjętą polityką dywidendy - dzielą się wypracowanymi zyskami.

Wśród badanych przedsiębiorstw (tabela 2) wchodzących w skład Dow Jones Industrial Average Index programy automatycznej reinwestycji dywidendy oferowały wszystkie blue chips. Zgodnie z przyjętą praktyką w Stanach Zjednoczonych dywidendy wypłacane są z reguły w ujęciu kwartalnym, tym samym akcjonariusze uczestniczący w programach automatycznej reinwestycji dywidendy nabywają udziały zgodnie z częstotliwością wypłat dywidend. Konstrukcja programów może zakładać możliwość udzielenia dyskonta w stosunku do aktualnej ceny akcji. Jednakże z analizy programów automatycznej reinwestycji dywidendy wynika, że 
przedsiębiorstwa tworzące Dow Jones Industrial Average Index takiego dyskonta przy nabywaniu akcji $\mathrm{w}$ ramach reinwestycji dywidendy nie udzielały. Uczestnicy programów mają pewność, że agent transferowy zakupi w ich imieniu udziały, wykorzystując pełną kwotę pozostawioną do dyspozycji po pomniejszeniu opłat, co prowadzi do tego, że na kontach występują również udziały ułamkowe.

Tabela 2. Programy automatycznej reinwestycji dywidendy realizowane przez spółki wchodzące w skład Dow Jones Industrial Average Index (stan na dzień 31.10.2020)

\begin{tabular}{|c|c|c|c|c|c|c|c|c|}
\hline Lp. & Nazwa spółki & DRIP & $\mathrm{D}$ & O-DRIP & SPP & $\begin{array}{l}\text { SPP } \\
\text { MIN }\end{array}$ & SPP MAX & O-SPP \\
\hline 1. & \begin{tabular}{|l|} 
International \\
Business Machines
\end{tabular} & tak & nie & $2 \%, \max 3 \$$ & tak & $50 \$$ & $250000 \$$ & $1 \$-5 \$$ \\
\hline 2. & Exxon Mobil & tak & nie & brak & tak & $50 \$$ & $250000 \$$ & brak \\
\hline 3. & Chevron & tak & nie & $\begin{array}{l}5 \%, \max 3 \$+5 \phi / \\
\text { szt./ brak }\end{array}$ & tak & $250 \$$ & $100000 \$$ & $2 \$+5 \phi / s z t$ \\
\hline 4. & Procter \& Gamble & tak & nie & brak & tak & $50 \$$ & $60000 \$$ & $\begin{array}{l}2 \phi / \text { szt. } \\
2,50 \$+2 \notin / \text { szt. }\end{array}$ \\
\hline 5. & $3 \mathrm{M}$ & tak & nie & brak & tak & $10 \$$ & $\begin{array}{l}10000 \$ / \\
\text { kwartał }\end{array}$ & brak \\
\hline 6. & Johnson \& Johnson & tak & nie & brak & tak & $25 \$$ & $50000 \$$ & $0 \$-1 \$$ \\
\hline 7. & McDonald's & tak & nie & $5 \%, \max 2 \$$ & tak & $50 \$$ & $250000 \$$ & $\begin{array}{l}2,50 \$+5 \phi / \text { szt. } \\
5 \$+5 \phi / \text { szt. }\end{array}$ \\
\hline 8. & Wal-Mart Stores & tak & nie & brak & tak & $50 \$$ & $150000 \$$ & $\begin{array}{l}1 \$+5 \phi / \text { szt. } \\
5 \$+5 \phi / \text { szt. }\end{array}$ \\
\hline 9. & United Technologies & tak & nie & $5 \%, \max 3 \$$ & tak & $50 \$$ & $250000 \$$ & $\begin{array}{l}2,50 \$+3 \phi / \text { szt. } \\
5 \$+3 \phi / \text { szt. }\end{array}$ \\
\hline 10. & Coca-Cola & tak & nie & $5 \%, \max 3 \$$ & tak & $50 \$$ & $250000 \$$ & $\begin{array}{l}2 \$+3 \phi / \text { szt. } \\
3 \$+3 \phi / \text { szt. }\end{array}$ \\
\hline 11. & Boeing & tak & nie & $5 \%, \max 5 \$$ & tak & $50 \$$ & $100000 \$$ & $\begin{array}{l}2,50 \$+5 \phi / \text { szt. } \\
5 \$+5 \phi / \text { szt. }\end{array}$ \\
\hline 12. & Caterpillar & tak & nie & $5 \%+3 \phi /$ szt. $/$ brak & tak & $25 \$$ & $250000 \$$ & $\begin{array}{l}1 \$+3 \phi / \text { szt. } \\
2,50 \$+3 \phi / \text { szt. }\end{array}$ \\
\hline 13. & JPMorgan Chase & tak & nie & brak & tak & $50 \$$ & $250000 \$$ & $\begin{array}{l}2 \$+3 \phi / \text { szt. } \\
5 \$+3 \phi / \text { szt. }\end{array}$ \\
\hline 14. & Hewlett-Packard & tak & nie & $5 \%, \max 3 \$$ & tak & $50 \$$ & $250000 \$$ & $\begin{array}{l}2,50 \$+6 \phi / \text { szt. } \\
3,50 \$+6 \notin / \text { szt. }\end{array}$ \\
\hline 15. & $\begin{array}{l}\text { Verizon } \\
\text { Communications } \\
\end{array}$ & tak & nie & $5 \%, 1 \$ \min / 3 \$ \max$ & tak & $50 \$$ & $200000 \$$ & $\begin{array}{l}2,50 \$+3 \phi / \text { szt. } \\
5 \$+3 \phi / \text { szt. }\end{array}$ \\
\hline 16. & AT\&T & tak & nie & $5 \%, \max 3 \$$ & tak & $50 \$$ & $120000 \$$ & $\begin{array}{l}2,50 \$+5 \phi / \text { szt. } \\
5 \$+5 \phi / \text { szt. }\end{array}$ \\
\hline 17. & Kraft Foods & tak & nie & $4 \%, \max 2 \$$ & tak & $50 \$$ & $250000 \$$ & $\begin{array}{l}0,80 \$+3 \notin / \text { szt. } \\
3 \$+3 \phi / \text { szt. }\end{array}$ \\
\hline 18. & \begin{tabular}{|l} 
E.I. DuPont de \\
Nemours \\
\end{tabular} & tak & nie & $5 \%, \max 5 \$$ & tak & $50 \$$ & $250000 \$$ & $\begin{array}{l}2,50 \$+5 \phi / \text { szt. } \\
5 \$+5 \phi / \text { szt. }\end{array}$ \\
\hline 19. & Merck & tak & nie & $4 \%, \max 2 \$+1 \phi / \mathrm{szt}$ & tak & $50 \$$ & $50000 \$$ & $\begin{array}{l}2 \$+1 \phi / \text { szt. } \\
5 \$+1 \phi / s z t .\end{array}$ \\
\hline 20. & Walt Disney & tak & nie & $2 \phi / s z t$ & tak & $50 \$$ & $250000 \$$ & $\begin{array}{l}1 \$+2 \phi / \text { szt. } \\
7 \$+2 \phi / \text { szt. }\end{array}$ \\
\hline 21. & Home Depot & tak & nie & $5 \%, \max 2,50 \$$ & tak & $50 \$$ & $250000 \$$ & $\begin{array}{l}5 \%, \max 5 \$+5 \\
c / \text { szt. }\end{array}$ \\
\hline
\end{tabular}


Pobrane z czasopisma Annales H - Oeconomia http://oeconomia.annales.umcs.pl Data: 26/04/2023 11:10:38

PROGRAMY AUTOMATYCZNEJ REINWESTYCJI DYWIDENDY..

\begin{tabular}{|c|c|c|c|c|c|c|c|c|}
\hline Lp. & Nazwa spółki & DRIP & $\mathrm{D}$ & O-DRIP & SPP & $\begin{array}{l}\text { SPP } \\
\text { MIN }\end{array}$ & SPP MAX & O-SPP \\
\hline 22. & Microsoft & tak & nie & $5 \%, \max 3 \$ /$ brak & tak & $25 \$$ & $250000 \$$ & $\begin{array}{l}2,50 \$+6 \phi / \text { szt. } \\
5 \$+6 \phi / \text { szt. }\end{array}$ \\
\hline 23. & American Express & tak & nie & $5 \%, \max 5 \$$ & tak & $50 \$$ & $120000 \$$ & $5 \$+5 \phi /$ szt. \\
\hline 24. & Bank of America & tak & nie & brak & tak & $50 \$$ & $120000 \$$ & brak \\
\hline 25 . & Pfizer & tak & nie & $5 \%, \max 3 \$$ & tak & $50 \$$ & $120000 \$$ & $\begin{array}{l}2,50 \$+5 \phi / \text { szt. } \\
5 \$+5 \phi / \text { szt. }\end{array}$ \\
\hline 26. & General Electric & tak & nie & brak & tak & $10 \$$ & $\begin{array}{l}10000 \$ / \\
\text { trans. }\end{array}$ & $1 \$-3 \$$ \\
\hline 27. & Intel & tak & nie & $5 \%, \max 3 \$$ & tak & $50 \$$ & $100000 \$$ & $2 \$-5 \$$ \\
\hline 28. & Alcoa & tak & nie & brak & tak & $25 \$$ & $5000 \$$ & $0 \$-1 \$$ \\
\hline 29. & Citigroup & tak & nie & brak & tak & $50 \$$ & $120000 \$$ & $2,50 \$-5 \$$ \\
\hline 30. & General Motors & tak & nie & brak & tak & $50 \$$ & $250000 \$$ & brak \\
\hline
\end{tabular}

DRIP - program automatycznej reinwestycji dywidendy (dividend reinvestment program, DRIP); D - dyskonto od reinwestowanych dywidend; O-DRIP - opłata za reinwestycję dywidendy; SPP - program zakupu akcji (share purchase plan, SPP); SPP MIN - minimalna transakcja; SPP MAX - maksymalna wartość inwestycji; O-SPP - opłata za zakup w podziale na systematyczne lub jednorazowe płatności

Źródło: opracowanie własne na podstawie stron internetowych agentów transferowych lub administratorów programów automatycznej reinwestycji dywidendy (www-us.computershare.com/Investor/\#DirectStock; www.dripadvice.com/ all_plans.html; https://directinvesting.com/index.cfm).

Ważną cechą programów wpływających na ich efektywność są opłaty ponoszone przez inwestorów. Z zestawienia zamieszczonego w tabeli 2 wynika, że z grupy 30 analizowanych programów automatycznej reinwestycji dywidendy $11 \mathrm{z}$ nich zakłada brak opłat dla uczestników programu. Bezpłatne programy automatycznej reinwestycji dywidendy (tzw. No-Fee Dividend Reinvestment Programs) nie przewidują opłat dla ich uczestników, a koszty związane z funkcjonowaniem programów automatycznej reinwestycji dywidendy przejmują na siebie spółki oferujące takie programy. W przypadku trzech przedsiębiorstw (tj. spółek Chevron, Caterpillar i Microsoft) opłaty za reinwestycję dywidendy uzależnione były od ilości posiadanych akcji. I tak zwolnienie z opłat w przypadku spółek Chevron oraz Caterpillar miało miejsce pod warunkiem posiadania co najmniej 200 akcji, a w przypadku spółki Microsoft - 100 akcji. Pozostałe analizowane programy przewidywały opłaty za nabycie akcji z wypłacanych dywidend. Najczęściej opłaty stanowiły przyjęty procent dywidendy podlegającej reinwestycji z określoną górną granicą kwotową.

Często programy automatycznej reinwestycji dywidendy uzupełniane są o dodatkowe programy zakupu akcji, określane jako Optional Cash Purchase Plans (OCPs) lub Stock Purchase Plans (SPPs). W przypadku badanych przedsiębiorstw tego rodzaju programy oferowały wszystkie spółki z Dow Jones Industrial Average Index. Tym samym uczestnicy programów automatycznej reinwestycji dywidendy mają możliwość nie tylko zakupu udziałów, reinwestując dywidendy gotówkowe, lecz także nabywania akcji, angażując dodatkowe środki niepochodzące z dywidend. Programy zakupu akcji mają z reguły określoną minimalną wartość pojedynczej transakcji oraz maksymalny limit inwestycji. W przypadku minimalnej wartości 
pojedynczej transakcji często przyjmowanym progiem jest 50 \$, choć może to być zarówno niższy poziom, jak w przypadku spółek 3M oraz General Electric (10 \$), lub wyższy, jak w przypadku spółki Chevron ( 250 \$). Programy zakupu akcji określały również maksymalny limit transakcji. W przypadku 14 programów określono go na nie więcej niż 250000 W ciągu roku. W pozostałych programach zostały wyznaczone limity na niższym poziomie, np. spółka Alcoa przyjęła maksymalny poziom transakcji w wysokości 5000 \$, a spółka 3M określiła limit na $10000 \$$, liczony w odniesieniu do kwartału. Inną spółką wyróżniającą się na tle pozostałych jest General Electric, gdzie poziom 10000 \$ odnosił się do pojedynczej transakcji, a nie do określonego horyzontu czasu (np. kwartału czy roku). Uczestnicy dodatkowych programów zakupu rzadziej niż w przypadku programów reinwestycji dywidendy mogli liczyć na brak opłat przy nabywaniu dodatkowych udziałów. Co więcej, opłaty związane z nabywaniem akcji w ramach dodatkowych programów zakupu były wyższe w przypadku jednorazowych wpłat niż powtarzających się transakcji. Poszczególne przedsiębiorstwa oferujące programy realizowały różną politykę w zakresie pobieranych opłat od uczestników programów. Najczęściej wdrażany był model opłat składający się z opłaty stałej oraz zmiennej; niektóre spółki przyjmowały stały poziom opłat niezależny od wielkości transakcji, z kolei inne określały maksymalną wielkość pobieranych prowizji.

Z funkcjonowaniem programów automatycznej reinwestycji dywidendy wiążą się również opłaty pobierane z tytułu operacji sprzedaży, które nie zostały zamieszczone w tabeli 2. Opłaty te są zróżnicowane w poszczególnych spółkach. Składa się na nie $z$ reguły stała opłata pobierana za operację sprzedaży oraz zmienna opłata pobierana za przetwarzanie zleceń rynkowych, której wysokość uzależniona jest od liczby sprzedawanych akcji.

\section{Zakończenie}

Plany automatycznej reinwestycji dywidendy stanowią popularne narzędzie wykorzystywane w polityce wypłaty dywidendy przedsiębiorstw w Stanach Zjednoczonych. Koncepcja programów reinwestycji dywidendy zakłada wykorzystanie środków pieniężnych zgromadzonych z tytułu wypłaty dywidendy pieniężnej na zakup akcji przedsiębiorstwa. $\mathrm{Z}$ analizy programów automatycznej reinwestycji dywidendy oferowanych przez spółki tworzące Dow Jones Industrial Average Index wynika, że mogą one stanowić atrakcyjny sposób nabywania akcji oraz budowy dhugoterminowego portfela papierów wartościowych.

Z przeprowadzonych badań wynika przede wszystkim to, że programy automatycznej reinwestycji dywidendy oferowały wszystkie spółki wchodzące w skład Dow Jones Industrial Average Index. Reinwestowane dywidendy gotówkowe w nowe udziały nabywane były przez uczestników programów bez udzielanego dyskonta w stosunku do aktualnej ceny akcji. Wiele programów automatycznej reinwestycji 
dywidendy funkcjonowało na zasadzie tzw. bezpłatnych programów (No-Fee Dividend Reinvestment Programs), które zwalniały uczestników z uiszczania opłat za nabywanie akcji. Co więcej, wszystkie spółki realizujące programy automatycznej reinwestycji dywidendy pozwalały ich uczestnikom na nabywanie akcji z dodatkowych środków niepochodzących $z$ dywidend w ramach oferowanych dodatkowych programów zakupu akcji (OCPs).

Plany (programy) automatycznej reinwestycji dywidendy jak dotąd nie zostały wprowadzone przez żadną z polskich spółek notowanych na Giełdzie Papierów Wartościowych w Warszawie. Głównym narzędziem stosowanej polityki dywidendy na rynku kapitałowym w Polsce jest klasyczna dywidenda pieniężna. W kontekście przedstawionych założeń planów automatycznej reinwestycji dywidendy oraz korzyści z tytułu ich funkcjonowania należy mieć nadzieję, że w przyszłości tego rodzaju plany będą podstawą budowy nowoczesnej polityki wypłaty dywidendy w Polsce.

\section{Bibliografia}

\section{Literatura}

Baker, H.K. (2009). Dividends and Dividend Policy. New Jersey: John Wiley \& Sons, Inc. doi:10.1002/9781118258408

Baker, H.K., Khan, W.A., \& Mukherjee, T.K. (2002). Direct Investing: The Role of Stock Purchase Plans. Financial Services Review, 11(1).

Baker, H.K., \& Powell, G. (2005). Understanding Financial Management: A Practical Guide. Oxford: Blackwell Publishing.

Berkman, H., \& Koch, P.D. (2017). DRIPs and the Dividend Pay Date Effect. Journal of Financial and Quantitative Analysis, 52(4), 1765-1795. doi:10.1017/S0022109017000394

Bierman, H. (1997). The dividend reinvestment plan puzzle. Applied Financial Economics, 1(3), $267-271$. doi:10.1080/096031097333628

Boehm, T.P., \& DeGennaro, R.P. (2007). A discrete choice model of dividend reinvestment plans: Classification and prediction. Working Paper, No. 2007-22, Federal Reserve Bank of Atlanta, Atlanta, GA.

Chan, K.K.W., McColough, D.W., \& Skully M.T. (1995). Dividend reinvestment plans in Australia. Global Finance Journal, 6(1), 79-99. doi:10.1016/1044-0283(95)90013-6

Cherin, A.C., \& Hanson, R.C. (1995). Dividend reinvestment plans: A review of the literature. Financial Markets, Institutions and Investments, 4.

Chiang, K., Frankfurter, G.M., \& Kosedag, A. (2005). Exploratory analyses of dividend reinvestment plans and some comparisons. International Review of Financial Analysis, 14(5), 570-586. doi:10.1016/j.irfa.2004.10.020

Finnerty, J. (1989). New issue dividend reinvestment plans and the cost of capital. Journal of Business Research, 18(2), 127-139. doi:10.1016/0148-2963(89)90031-3

Kaźmierska-Jóźwiak, B. (2019). Polityka wypłat na rzecz akcjonariuszy. Determinanty - reakcja rynku ocena. Łódź: Wydawnictwo Uniwersytetu Łódzkiego.

Kuciński, A., \& Byczkowska, M. (2017). Buy-back akcji własnych w celu ich umorzenia. Ekonomiczne Problemy Ustug, 2(127), 131-141. doi:10.18276/epu.2017.127-12

Larkin, P., Lee, B., \& Wane, A. (2005). Repurchase Dividend Reinvestment Plans (Repurchase DRIPS). Journal of Business \& Economics Research, 3(10). doi:10.19030/jber.v3i10.2819 
Mukherjee, T.K., Baker, H.K., \& Hingorani V.L. (2002). Why firms adopt and discontinue new-issue dividend reinvestment plans. Journal of Economics and Finance, 26(3), 284-296. doi:10.1007/BF02759712

Mukherjee, T.K., He, W., \& Baker, H.K. (2012). Why Firms Offer New-issue Direct Stock Purchase Plans. Journal of Applied Finance, 22(2), 113-123.

Ogden, J.P. (1994). A Dividend Payment Effect in Stock Returns. Financial Review, 29(3), 345-369. doi:10.1111/j.1540-6288.1994.tb00401.x

Pettway, R.H., \& Malone R.P. (1973). Automatic Dividend Reinvestment Plans of Nonfinancial Corporations. Financial Management, 2(4), 11-18.

Pieloch, A. (2013). Dywidenda niepieniężna jako narzędzie restrukturyzacji kapitałowej i właścicielskiej przedsiębiorstwa. W: R. Borowiecki, J. Chadam, J. Kaczmarek (red.), Zachowania przedsiębiorstw w obliczu nowych wyzwań gospodarczych. Restrukturyzacja - zarzadzanie - analiza (s. 433-448). Kraków: Uniwersytet Ekonomiczny w Krakowie.

Scholes, M.S., \& Wolfson, M.A. (1989). Decentralized investment banking: The case of dividend-reinvestment and stock-purchase plans. Journal of Financial Economics, 24(1), 7-35. doi:10.1016/0304-405X(89)90070-6

Sierpińska, M. (1999). Polityka dywidend w spółkach kapitatowych. Warszawa-Kraków: Wydawnictwo PWN.

Zarębski, S. (2011). Plany bezpośrednich reinwestycji dywidend (DRIPs) jako element polityki finansowej małych i średnich przedsiębiorstw. Zeszyty Naukowe Uniwersytetu Szczecińskiego. Ekonomiczne Problemy Ustug, (81), 179-188.

Zarębski, S. (2013). Alternatywne formy wypłat inwestorskich w polityce dywidend spółek niepublicznych. Zarządzanie i Finanse, 11(2/2), 607-618.

\section{Strony internetowe}

https://directinvesting.com/index.cfm www-us.computershare.com/Investor/\#DirectStock

www.dripadvice.com/all_plans.html www.dripinvestor.com/index.asp 